\title{
KEBIJAKAN HUTANG, KEPUTUSAN INVESTASI, DAN PROFITABILITAS DALAM MENGUNGKIT NILAI PERUSAHAAN
}

\author{
Yulifita Ayuningtyas \\ Universitas Merdeka Malang \\ Wahyu Wiyani \\ Universitas Merdeka Malang \\ wahyu.wiyani@unmer.ac.id \\ Eko Agus Susilo \\ Universitas Merdeka Malang \\ ekoagussusilo@unmer.ac.id
}

\section{Suggested Citation:}

Pertiwi, Tommy, Tumiwa. (2015). Pengaruh Kebijakan Hutang, Keputusan Investasi, dan Profitabilitas terhadap Nilai Perusahaan. Universitas Sam Ratulangi Manado

\begin{abstract}
:
The purpose of this study is to determine and explain the effect of debt policy, investment decisions and profitability on the relationship in leveraging company value. The method used in this research is quantitative research with explanatory research approach. The sample used in this study is a food and beverages company that was listed on the Indonesia Stock Exchange in 2015-2018 using multiple linear regression as a data analysis tool. The results showed that both partially and simultaneously, debt policy, investment decisions and profitability had a positive and significant effect on firm value.
\end{abstract}

Keyword : Debt Policy, Firm Value, Investment Decision, Profitability

\section{Abstrak:}

Tujuan penelitian ini adalah untuk mengetahui dan penjelaskan pengaruh kebijakan hutang, keputusan investasi dan profitabilitas terhadap kaitannya di dalam mengungkit nilai perusahaan. Metode yang digunakan di dalam penelitian ini adalah penelitian kuantitatif dengan pendekatan penelitian eksplanatori. Sampel yang digunakan di dalam penelitian ini adalah perusahaan food and beverages yang listing di Bursa Efek Indonesia pada tahun 2015-2018 dengan menggunakan regresi linier berganda sebagai alat analisis data. Hasil penelitian menunjukkan baik secara parsial maupun simultan, kebijakan hutang, keputusan investasi dan profitabilitas berpengaruh positif dan signifikan terhadap nilai perusahaan.

Kata Kunci: Kebijakan Hutang, Keputusan Investasi, Nilai Perusahaan, Profitabilitas

JEL Classification : G32, M16, 


\section{Pendahuluan}

Perkembangan perekonomian di Indonesia telah mengalami kemajuan yang sangat pesat, berefek pada persaingan yang sangat ketat dalam segala bidang usaha termasuk perusahaan manufaktur. Persaingan perusahaan manufaktur akan mendorong para manajer perusahaan untuk mengembangkan usahanya sekaligus juga memikirkan ide-ide kreatif dan inovatif dalam mengembangkan usahanya untuk mencapai tujuan perusahaan. Menurut Endarmawan (2014), tujuan dididirikan perusahaan adalah untuk mencapai keuntungan yang maksimal atau laba yang sebesar-besarnya, memakmurkan pemilik perusahaan atau para pemilik dan memaksimalkan nilai perusahaan yang tercermin pada harga sahamnya

Mempertahankan kontinuitas perusahaan adalah elemen penting yang harus dipertahankan oleh suatu perusahaan yang sedang menjalankan usahanya, dalam mengembangkan usahanya suatu perusahaan pasti membutuhkan modal yang sangat besar, yang secara umum terdiri dari sumber pembiayaan internal dan sumber pembiayaan eksternal perusahaan. Sumber pendanaan internal perusahaan antara lain: 1) asset pribadi atau modal dari pemilik perusahaan itu sendiri, 2) laba ditahan / besarnya laba perusahaan yang diperoleh atau dihasilkan pada suatu periode tertentu yang tidak dibagikan sebagai deviden oleh perusahaan. 3) penyusutan .

Sumber pendanaan eksternal berasal dari para kreditur dan hutang kepada bank atau kepada sumber dana lainnya yang berada diluar perusahaan tersebut. Pendanaan ini sering disebut dengan debt financing.

Dalam mendapatkan sumber pendanaan, maka perusahaan haruslah memiliki nilai perusahaan yang tinggi. Nilai perusahaan adalah kinerja perusahaan yang dicerminkan oleh harga saham yang dibentuk oleh permintaan dan penawaran pasar modal yang merefleksikan penilaian masyarakat terhadap kinerja perusahaan (Harmono, 2009). Nilai perusahaan yang tinggi merupakan salah satu tujuan dari perusahaan. Nilai perusahaan merupakan persepsi investor mengenai tingkat keberhasilan perusahaan yang sering dikaitkan dengan harga saham.

Untuk meningkatkan nilai salah satu keputusan penting yang diambil perusahaan adalah keputusan investasi. Keputusan investasi dilakukan guna meningkatkan nilai perusahaan serta mempertahankan eksistensi perusahaan. Investasi yang dilakukan perusahaan salah satunya bisa dibiayai dengan hutang sehingga kebijakan hutang menjadi sesuatu yang perlu mendapatkan pemikiran serius bagi perusahaan. Kebijakan hutang merupakan kebijakan perusahaan tentang seberapa jauh perusahaan menggunakan hutang sebagai sumber pendanaannya. Penggunaan kebijakan hutang dapat digunakan untuk menciptakan nilai perusahaan yang diinginkan. Penggunaan hutang tetaplah harus dikelola dengan baik karena itu merupakan hal yang sensitif bagi perusahaan terhadap tinggi dan rendahnya nilai perusahaan. Semakin tinggi proporsi hutang yang ditetapkan perusahaan pada tingkat tertentu maka semakin tinggi nilai perusahaan, namun apabila tingkat hutang melampaui proporsi yang ditetapkan oleh perusahaan maka yang akan terjadi adalah penurunan nilai perusahaan.

Keputusan investasi serta penggunaan hutang akan mempengaruhi profitabilitas perusahaan. Profitabilitas merupakan rasio untuk menilai kemampuan perusahaan dalam mencari keuntungan (Kasmir, 2011). Profitabilitas menunjukkan efektivitas perusahaan dalam menghasilkan tingkat keuntungan dengan serangkaian pengelolaan asset yang dimiliki perusahaan. Tingkat profitabilitas yang tinggi akan mampu meningkatkan nilai perusahaan, karena tingkat kepercayaan masyarakat utamanya investor akan meningkat. Berdasarkan uraian yang telah dijelaskan, maka tujuan penelitian ini adalah untuk mengetahui pengaruh kebijakan hutang, keputusan investasi dan profitabilitas dalam meningkatkan nilai perusahaan

\section{Kajian Literatur}

\section{Kebijakan Hutang dan Nilai perusahaan}

Kebijakan hutang merupakan kebijakan pendanaan perusahaan yang bersumber dari eksternal. Kebijakan hutang menggambarkan hutang jangka panjang yang dimiliki oleh perusahaan untuk membiayai operasional perusahaan. Penentuan kebijakan hutang berkaitan dengan struktur modal karena hutang merupakan salah satu komposisi dalam strktur modal. Menurut Hanafi (2004) perusahaan dinilai beresiko apabila memiliki porsi hutang yang besar pada struktur modal, tetapi bila perusahaan menggunakan hutang yang kecil atau tidak sama sekali maka perusahaan dinilai tidak dapat memanfaatkan tambahan modal eksternal yang dapat meningkatkan 
operasional perusahaan. Penelitian yang dilakukan oleh Herawati (2013) menemukan hasil bahwa kebijakan hutang atau leverage berpengaruh tidak signifikan terhadap nilai perusahaan. Hasil yang tidak signifikan menandakan bahwa kebijakan hutang yang telah ditetapkan perusahaan tidak memberikan pengaruh yang cukup besar bagi nilai perusahaan.

\section{Pengaruh Keputusan Investasi dan Nilai Perusahaan}

Keputusan investasi diukur dengan menggunakan Price Earning Ratio (PER). Peningkatan nilai perusahaan dari investasi ini akan tercermin pada meningkatnya harga saham. Dengan kata lain, keputusan investasi harus dinilai dalam hubungannya dengan kemampuannya dalam menghasilkan keuntungan yang sama atau lebih besar dari yang di syaratkan oleh pemilik modal. Pengertian nilai disini adalah nilai intrinsik investasi yang tidak lain adalah sebesar nilai sekarang dari aliran kas yang diharapkan atas inventasi. Penelitian yang dilakukan oleh Indarti (2012) dan Wijaya dan Wibaya (2010) yang menyebutkan bahwa nilai perusahaan yang dibetuk melalui indikator nilai pasar saham sangat dipengaruhi oleh pengeluaran investasi dan pengeluaran discretionary di masa yang akan datang.

\section{Profitabilitas dan Nilai Perusahaan}

Profitabilitas adalah cerminan oleh kinerja manajemen dalam menjalankan perusahaan. Menurut Sartono (2011) profitabilitas adalah kemampuan perusahaan memperoleh laba dalam hubungannya dengan penjualan, total aktiva maupun modal sendiri. Profitabilitas dapat diukur dengan return on Equity, Return On Assets, rasio ini mencerminkan tingkat pengembalian yang diperoleh dari aseet dan modal perusahaan. Penellitian yang dilakukan oleh Hermuning (2013) mengenai pengaruh profitabilitas, growth opportunity, struktur modal terhadap nilai perusahaan pada perusahaan publik di Indonesia yang menyatakan bahwa profitabilitas berpengaruh positif dan signifikan terhadap nilai perusahaan. Penelitian tersebut sejalan dengan penelitian yang dilakukan oleh Rina (2012) mengatakan bahwa profitabilitas berpengaruh terhadap nilai perusahaan.

\section{Metode}

Jenis penelitian yang digunakan oleh peneliti adalah jenis penelitian eksplanatori (Explanatory Research). Sampel dalam penelitian adalah perusahaan food and beverage yang terdaftar pada Bursa Efek Indonesia (BEI) periode 2015-2018 sejumlah 13 perusahaan menggunakan metode purposive sampling. Teknik analisis data yang digunakan adalah regresi linier berganda.

Hasil

Uji $t$ atau uji parsial digunakan untuk menguji pengaruh parsial dari masing-masing variabel independen yaitu kebijakan hutang, keputusan investasi, dan profitabilitas terhadap variabel dependen yaitu nilai perusahaan. Hasil dari uji t disajikan dalam tabel berikut: 
Tabel 1

Hasil Uji Hipotesis $\mathbf{t}$

\begin{tabular}{|c|c|c|c|c|c|c|}
\hline \multicolumn{7}{|c|}{ Coefficients $^{a}$} \\
\hline & & Unstan & Coefficients & $\begin{array}{l}\text { Standardized } \\
\text { Coefficients }\end{array}$ & & \\
\hline \multicolumn{2}{|l|}{ Model } & $\bar{B}$ & Std. Error & Beta & $t$ & Sig. \\
\hline \multirow[t]{4}{*}{1} & (Constant) & $-7,654$ & 1,700 & & $-4,501$ & ,000 \\
\hline & DER & 6,813 & 1,331 & ,292 & 5,120 &, 000 \\
\hline & PER &,- 045 & ,003 &,- 834 & $-13,890$ &, 000 \\
\hline & ROA & ,712 & ,065 & ,657 & 10,923 &, 000 \\
\hline
\end{tabular}

Sumber : Data diolah (2020)

Berdasarkan hasil tersebut, dapat disimpulkan bahwa kebijakan hutang, keputusan investasi, dan profitabilitas secara parsial memiliki pengaruh signifikan terhadap nilai perusahaan.

Selanjutnya, peneliti menggunakan uji $F$ atau uji simultan di dalam penelitian ini. Uji $F$ ini digunakan untuk mengetahui pengaruh Kebijakan hutang, Kebijakan investasi, dan Profitabilitas secara simultan terhadap Nilai Perusahaan.

Tabel 2

Hasil Uji F

ANOVAa $^{a}$

\begin{tabular}{lllllll}
\hline Model & & Sum of Squares & df & Mean Square & F & Sig. \\
\hline 1 & Regression & 6544,256 & 3 & 2181,419 & 88,454 &, $000^{\mathrm{b}}$ \\
& Residual & 1183,760 & 48 & 24,662 & & \\
& Total & 7728,017 & 51 & & & \\
\hline
\end{tabular}

a. Dependent Variable: PBV

b. Predictors: (Constant), ROA, DER, PER

Sumber : Data diolah (2020)

Berdasarkan hasil yang terdapat pada tabel 2. diketahui nilai signifikan adalah sebesar 0,00 kurang dari nilai $a=0,05$. Hal ini menunjukkan bahwa kebijakan hutang, keputusan investasi dan profitabilitas secara simultan atau bersama-sama berpengaruh secara signifikan terhadap nilai perusahaan. Artinya terdapat pengaruh yang besar kebijakan hutang, keputusan investasi dan profitabilitas terhadap nilai perusahaan.

\section{Pembahasan}

\section{Pengaruh Kebijakan hutang terhadap nilai perusahaan}

Hasil pengujian ini menunjukkan bahwa kebijakan hutang nilai perusahaanerpengaruh secara signifikan terhadap nilai perusahaan, artinya apabila suatu perusahaan dapat menggunakan hutang dengan sebaik mungkin maka hutang tersebut dapat mengungkit/meningkatkan nilai perusahaan. Sebagai salah satu sumber pendanaan bagi perusahaan, penggunaan hutang memang memiliki risiko lebih besar dibanding dengan penggunan modal sendiri, namun pengelolaam hutang yang tepat dalam menjalankan operasional perusahaan, hutang akan bisa meningkatkan profitabilitas perusahaandalam upaya meningkatkan kepercayaan masyarakat serta meningkatkan nilai perusahaan yang tercermin dalam harga saham perusahaan di pasar modal. Hasil penelitian ini konsisten dengan hasil penelitian yang sebelumnya pernah dilakukan oleh Tumiwa, Tommy dan Pertiwi (2016). kebijkan hutang secara persial berpengaruh terhadap nilai perusahaan.

\section{Pengaruh Keputusan investasi terhadap nilai perusahaan}

Uji secara parsial menunjukkan hasil bahwa keputusan investasi secara signifikan mempengaruhi nilai perusahaan artinya kebijakan dalam memilih investasi yang tepat akan dapat meningkatkan nilai perusahaan, 
keputusan investasi terkait dengan seberapa besar dana yang kita investasikan kedalam suatu aset akan mampu memberikan tingkat return dimasa mendatang, jika keputusan investasi tersebut mampu memberikan return yang menguntungkan maka akan meningkatkan pula bagian keuntungan yang akan dinikmati oleh pemegang saham yang tentunya ini semua akan meningkatkan/mengungkin nilai perusahaan

Hasil penelitian ini sejalan dengan penelitian yang dilakukan oleh Tumiwa, Tommy dan Pertiwi (2016). Yang menunjukkan hasil bahwa keputusan investasi secara persial berpengaruh terhadap nilai perusahaan. Sari (2019) dalam penelitiannya juga menemukan hasil yang sama bahwa keputusan investasi berpengaruh signifikan terhadap nilai perusahaan.

\section{Pengaruh Profitabilitas terhadap nilai perusahaan}

Hasil penelitian menunjukkan bahwa profitabilitas secara signifikan mempengaruhi nilai perusahaan, artinya bahwa jika profitabilitas perusahaan maka perusahaan nilai perusahaan akan terungkit/meningkat. Hasil penelitian ini mendukung penelitian sebelumnya yang dilakukan oleh Tumiwa, Tommy dan Pertiwi (2016), dimana dalam penelitiannya ditemukan hasil bahwa profitabilitas secara persial berpengaruh signifikan terhadap nilai perusahaan, demikian juga hasil penelitian yang dilakukan Sari (2019) menunjukkan bahwa profitabilitas berpengaruh signifikan terhadap nilai perusahaan. Penelitian yang dilakukan oleh Martikarini (2015) menemukan hasil yang sama bahwa Profitabilitas yang diukur dengan ROE berpengaruh signifikan terhadap nilai perusahaan yang diukur dengan PBV. Begitu pula dengan Brimantyo, dkk (2019) yang menunjukkan hasil bahwa profitabilitas yang merupakan indikator dari kinerja keuangan perusahaan berpengaruh signifikan terhadap nilai perusahaan.

\section{Pengaruh Kebijakan hutang, keputusan investasi dan profitabilitas terhadap nilai perusahaan}

Hasil penelitian menemukan bahwa kebijakan hutang, keputusan investasi dan profitabilitas secara simultan berpengaruh signifikan terhadap nilai perusahaan artinya penggunaan hutang yang tepat, investasi yang tepat dan profitabilitas yang tinggi dapat mengungkit/meningkatkan nilai perusahaan.

Pengungkapan atau informasi tentang kebijakan yang tepat serta informasi tentang kemampuan perusahaan meningkatkan keuntungan merupakan informasi yang sangat ditunggu oleh para investor, karena dengan mengetahui informasi yang baik dari paparan laporan keuangan suatu perusahaan maka akan meningkatkan atensi investor untuk membeli saham perusahaan yang bersangkutan. Informasi yang diterima oleh investor terlebih dahulu diterjemahkan sebagai sinyal yang baik (good news) atau sinyal yang jelek (bad news). Apabila laba yang dilaporkan oleh perusahaan meningkat maka informasi tersebut dapat dikategorikan sebagai sinyal baik karena mengindikasikan kondisi perusahaan yang baik. Sebaliknya apabila laba yang dilaporkan menurun maka perusahaan berada dalam kondisi tidak baik sehingga dianggap sebagai sinyal yang jelek. Brigham dan Houston (2006) menyatakan bahwa isyarat adalah suatu tindakan yang diambil manajemen perusahaan yang memberi petunjuk bagi investor tentang bagaimana manajemen memandang prospek perusahaan.

Hasil penelitian ini sejalan dengan penelitian Tumiwa, Tommy dan Pertiwi (2016) yang menemukan bahwa kebijkan hutang, keputusan investasi dan profitabilitas secara simultan berpengaruh signifikan terhadap nilai perusahaan. Penelitian yang dilakukan Sari (2019) juga menemukan hasil bahwa secara simultan, kebijakan hutang, keputusan investasi, dan profitabilitas berpengaruh signifikan terhadap nilai perusahaan. Penelitian Ali (2016) menemukan hasil kebijakan deviden, kebijakan hutang, profitabilitas dan keputusan investasi berpengaruh sebesar $97.1 \%$ terhadap nilai perusahaan.

\section{Kesimpulan}

Berdasarkan hasil penelitian ini, untuk meningkatkan kepercayaan investor yang tercermin dalam meningkatnya nilai perusahaan/ harga saham perusahaan di pasar maka kebijakan hutang, kebijakan investasi dan profitabilitas harus senantiasa menjadi perhatian utama pimpinan. Karena dengan manajemen yang tepat terhadap kebijakan hutang, kebijakan investasi dan perhatian terhadap profitabilitas perusahaan, akan terjaga 
keberlangsungan perusahaan sehingga tingkat kepercayaan masyaraat terhadap perusahaan meningkat yang berefek pada peningkatan nilai perusahaan.

\section{Daftar Pustaka}

Ali. (2016). Pengaruh Kebijakan Deviden, Kebijakan Hutang, Profitabilitas, Keputusan Investasi terhadap Nilai Perusahaan. Jurnal Akuntansi Sekolah Tinggi Ilmu Ekonomi Perbanas Surabaya.

Brigham \& Houston. (2006). Dasar-dasar Manajemen Keuangan. Edisi kesepuluh.Jakarta : Salemba Empat.

Brimantyo, H., Rochman, A. K., \& Karima, T. (2019). PENINGKATAN KINERJA KEUANGAN PERUSAHAAN MELALUI STRUKTUR MODAL UNTUK MENINGKATKAN NILAI PERUSAHAAN. Jurnal Bisnis Dan Manajemen, 6(1). doi:10.26905/jbm.v6i1.3030

Dini, Astri W., and lin Indarti. "Pengaruh Net Profit Margin (NPM), Return on Assets (ROA) Dan Return on Equity (ROE) Terhadap Harga Saham Yang Terdaftar Dalam Indeks Emiten LQ45 Tahun 2008 - 2010." Jurnal Kajian Akuntansi dan Bisnis, vol. 1, no. 1, 2012.

Endarmawan, Yogi. 2014. "Pengaruh Keputusan Investasi, Keputusan Pendanaan, dan Kebijakan Dividen terhadap Nilai Perusahaan". Artikel IImiah Mahasiswa 2014.

Hanafi, Mamduh. (2004). Manajemen keuangan, BPFE, Yogyakarta.

Harmono, 2009, Manajemen Keuangan Berbasis Balanced Scorecard (Pendekatan Teori, Kasus, dan Riset Bisnis), Bumi Aksara, Jakarta.

Herawati. (2013). Pengaruh kebijakan Deviden, kebijakan hutang dan profitabilitas terhadap nilai perusahaan. Universitas Negeri Padang. Ejournal.unp.ac.id vol. 2 No. 2.

Hermuningsih, S. (2013). Pengaruh profitabilitas, growth opportunity, struktur modal terhadap nilai perusahaan pada perusahaan publik di Indonesia. Buletin ekonomi moneter dan perbankan, 16(2), 127-148.

Kasmir. (2015). Analisis Laporan Keuangan. Jakarta: Rajawali Pers

Martikarini. (2015). Pengaruh profitabilitas, kebijakan hutang, dan deviden terhadap nilai perusahaan manufaktur yang terdaftar di BEl. Jurnal akuntansi fakultas ekonomi Universitas Gunadarma.

Pertiwi, Tommy, Tumiwa. (2015). Pengaruh Kebijakan Hutang, Keputusan Investasi, dan Profitabilitas terhadap Nilai Perusahaan. Universitas Sam Ratulangi Manado.

Sari. (2017). Pengaruh Kebijakan Hutang, Keputusan Investasi, dan profitabilitasterhadap Nilai Perusahaan. Jurnal Akuntansi Fakultas Ekonomi dan BisnisUniversitas Muhammadiyah Surakarta.

Sartono, Agus. (2011). Manajemen Keuangan (Teori dan Aplikasi). Yogyakarta : BPFE.

Wijaya, R.L.P. dan B.A.Wibawa. 2010. Pengaruh Keputusan Investasi, Keputusan Pendanaan, dan Kebijakan Dividen Terhadap Nilai Perusahaan. Simposium Nasional Akuntansi 13 Purwokerto. 